\title{
Gonadal development and gametogenesis in the threatened freshwater siluroid fish Horabagrus brachysoma (Gunther, 1864): a morpho-histological perspective
}

\author{
LEKSHMI R. CHANDRAN AND G. PRASAD \\ Department of Zoology, University of Kerala, Kariavattom, Thiruvananthapuram - 695 581, Kerala, India \\ e-mail:probios1@gmail.com
}

\begin{abstract}
The macro-morphology and histology of the reproductive system together with cytology of the process of gametogenesis in Asian sun catfish, Horabagrus brachysoma (Gunther, 1864) were investigated. A maturity key for horabagrids, based on macroscopic appearance of gonads at different stages of maturity was established for the first time. The distinctive features of male genital system were the digitiform testes, absence of seminal vesicles and five morphological maturity stages. Unrestricted semicystic spermatogenic activity with seven cytological stages was recognised viz., primordial germ cells, primary spermatogonia, secondary spermatogonia, primary spermatocytes, secondary spermatocytes, spermatids and spermatozoa. The classic cystovarian, group synchronic ovary, with five morphological maturity stages and a single spawning period were the peculiarities of female reproduction. The process of oogenesis progressed through five phases viz., previtellogenic, cytoplasmic growth, vitellogenic, yolky and mature. The sequence of oocyte maturation was: oogonia, chromatin nuclear, peri-nuclear, cortical alveolar, yolky and mature. Vitellogenesis was initiated in oocytes of maturing or stage-Il ovary. No liqueification of yolk was observed. Atresia was observed in vitellogenic and mature oocytes only. Corpus luteum like structure was present in ovaries with vitellogenic and yolky oocytes. A very prominent zona radiata of thickness $16.5 \mu \mathrm{m}$ covered mature oocytes.
\end{abstract}

Keywords: Breeding season, Gametogenesis, Horabagridae, Horabagrus brachysoma, Spermatogenesis, Teleost, Vitelline membrane

\section{Introduction}

Morphology of the male reproductive organ of Siluriformes is highly diversified (Santos et al., 2001). According to Grier and Parenti (2004), testes of teleosts can be classified into restricted or unrestricted spermatogenic types based on the spatial establishment of spermatogenesis. Some catfishes show a peculiar pattern of spermatogenesis, the semi cystic type that quite differs from the usual cystic spermatogenesis of teleosts only at the spermiogenic level (Mattei et al., 1993). Some families of catfishes possess accessory glandular organs arising from the common sperm duct called seminal vesicle (Chowdhury and Joy, 2007) with either secretary (Loir et al., 1989) or sperm storage activity (Legendre et al., 1996) or both. They appear in Ictaluridae (Sneed and Clemens, 1963), Bagridae (Rastogi, 1969), Heteropneustidae (Nayyar and Sunderraj, 1970), Clariidae (Mansour et al., 2002) and Siluridae (Mansour and Lahnsteiner, 2003). Catfishes such as Clariids (Sircar, 1970) and Pimelodids (Loir et al., 1989) exhibit fringed or digitiform testes during reproductive activity. Siluriformes possess ovary of classic "cystovarian type" as defined by Hoar (1969), as in other teleosts. For successful implementation of induced breeding, farming and conservation it is important to ascertain whether a species belongs to which of the three basic groups of spawning strategies: synchronous, group synchronous and asynchronous (Wallace and Selman, 1981).

The genus Horabagrus of the family Horabagridae (Sullivan et al., 2006) with only two recognised species viz., Horabagrus brachysoma (Gunther, 1864) and $H$. nigricollaris are endemic to the South Indian river systems originating from the Western Ghats, an exceptional hotspot of freshwater fish diversity. H. brachysoma abounds in the rivers, lakes and lowland water bodies of Kerala and Karnataka (Ali et al., 2007) while $H$. nigricollaris is known only from the type locality in Chalakudy River, Kerala (Prasad et al., 2008). The former species is a popular ornamental fish in aquarium pet market while it is demanded appreciably as a food fish in the local markets. A perusal of the recent literature shows that the species is gaining research attention and the major contributions are those of Padmakumar et al. (2011) on the breeding of this catfish in captive condition; Prasad (2014) on the effects of dietary protein levels on the growth and feed utilisation; Sahoo et al. (2017) on the embryonic and larval development and Sahoo et al. (2018) on the common deformities of the larvae of this 
catfish during the embryonic and larval development stages. No literature is available on the developmental pattern of gonads and gametogenesis of Horabagrids and hence an investigation regarding the morphofunctional organisation of the reproductive system of $H$. brachysoma was undertaken, in order to describe the gonadal development and gametogenesis in the species in comparison with other siluroid taxa.

\section{Materials and methods}

Specimens of $H$. brachysoma, captured by gillnets and hook and line were collected from local commercial fishery associated with major rivers of Kerala viz., Achenkovil (Prayikkara and Paypad), Chalakudy (Kankkankadavu and Moozhikulam), Pamba (Parumala and Neerettupuram) and Periyar (Manjaly and Angadikadavu). After measuring total length (TL) to the nearest $0.1 \mathrm{~cm}$ and total weight (TW) to the nearest $0.1 \mathrm{~g}$, the specimens (total 436) were preserved in $10 \%$ formaldehyde. To prepare a maturity key on a macroscopic scale, sex was identified, gonads were removed; weight, length, colour, vascularisation and extendibility to the visceral cavity were recorded. Gonadal stages were classified according to the modified maturity scale for Mystus montanus (Arockiaraj et al., 2004). Tissue samples from the cranial, middle and caudal part of the testes and from the middle part of ovary in each stage were fixed in Bouin's fluid, processed as per Pearse (1968), embedded in paraffin, serially sectioned at $2-5 \mu \mathrm{m}$ in a Leica microtome and stained with Haematoxylin - Eosin (H\&E) (Pearse, 1968). For demonstration of vitellogenic activity in oocytes, periodic acid Shiff's (PAS) and alcian blue stains were used. To describe the ovarian cycle, the developing oocytes were classified according to the size, morphology and composition into five phases (Unver and Saraydin, 2004): pre-vitellogenic, cytoplasmic growth, vitellogenic, yolky and mature oocyte. The thickness of vitelline membrane and diameter of oocyte as well as nucleus were measured under a research microscope.

\section{Results and discussion}

Maturity key established for H. brachysoma based on morphological observations of gonads is depicted in Table 1.

\section{Morpho-histology of testes}

Testes elongated, dual digitiform (Fig. 1a) and physically positioned close to the air bladder anteriorly and to kidneys posteriorly. Each testis, enclosed by a thick tunica albuginea, was attached to the dorsal body wall by the mesovarium. The fingers like projections observed along the entire length of testes were continuous interiorly and communicated with the centrally located spermatic duct. The spermatic ducts of right and left joined caudally to form a common spermatic duct that opened to the urinogenital aperture below the anus. There were no seminal vesicles and urinogenital papilla associated with the reproductive system of $H$. brachysoma. Tunica albuginea divided testes into numerous thin walled lobules enclosing discrete nests or cysts at various stages of spermatogenesis. But each cyst was synchronous containing cells at the same stage of development. Blood vessels, connective tissue and collagenous fibers were found inside the interstitial stroma. Towards the last phase of completion of spermatogenesis, the walls of the cysts formed by sertoli cells, opened up and the spermatids were discharged into the lobular lumen where these metamorphose to spermatozoa. Spermatogenic activity was observed to be unrestricted, being noticed along the entire length of the testes.

\section{Spermatogenesis}

The process of spermatogenesis progressed through the establishment of different spermatogenic cell types and phases were distinguishable on the basis of their characteristic nuclear and cytoplasmic morphology. These cell types occurring at different developmental stages are shown in Fig. $2(a-j)$.

In immature testes or stage I (Fig. 2a), the lobules lined by a single layer of germinal epithelium, appeared diminutive and thick walled. Surrounded by sertoli cells, spermatogonia, the largest of spermatogenic cells appeared along the basement membrane individually or some times double on the periphery of the lobules. These were weakly stained and had a distinct, central, large and round nucleus containing one or two nucleoli. In the secondary stage, these cells increased in number (2-4) and became enclosed in cysts (Fig. 2a). As the testes develop to the maturing phase or stage II (Fig. 2b,c) the lobules widens. The connective tissue present in the interlobular spaces became slightly reduced. Starting from the central part of the testes, rigorous spermatogenesis occurred. The lobule wall became thin and contained synchronic cysts in varying stages of spermatogenic activity. At an early stage, some spermatogonia and primary spermatocytes predominated. Primary spermatocytes originated mitotically from the secondary spermatogonia that appeared with a faint cytoplasm and a deeply stained nucleus. At later stage, they meiotically divided into secondary spermatocytes with a small nucleus and dispersed chromatin. Spermatids, the final products of meiosis, with deeply stained nucleus, originated from the secondary spermatocytes (Fig. 2d). Finally spermatogenesis got restricted to one or two cysts in a lobule. 
Table 1. Maturity key established for H. brachysoma based on morphological observations of gonads

\begin{tabular}{lll}
\hline Maturity Stages & Testis & Ovary \\
\hline Immature (Stage I ) & $\begin{array}{l}\text { Very narrow, white elongated delicate thread like testis; } \\
\text { clearly identified on microscopic observation; occupies } \\
1 / 4^{\text {th }} \text { of viscera. } \\
\text { Maturing (Stage II) }\end{array}$ & $\begin{array}{l}\text { Transparent, asymmetrically bi-lobed, } \\
\text { occupies } 1 / 4^{\text {th }} \text { of the body cavity. Eggs are } \\
\text { visible only under microscope. }\end{array}$ \\
& $\begin{array}{l}\text { right; from each testis numerous finger like lobes arises; } \\
\text { occupies } 1 / 2 \text { of the visceral cavity. }\end{array}$ & $\begin{array}{l}\text { Transparent or light yellowish; occupies } 1 / 2 \\
\text { of the body cavity. }\end{array}$ \\
Mature (Stage III) & $\begin{array}{l}\text { Finger like lobes of testis become prominent and turn } \\
\text { more pinkish; occupies } 2 / 3^{\text {rd }} \text { of the body cavity. }\end{array}$ & $\begin{array}{l}\text { Yellowish brown, occupies } 2 / 3^{\text {rd }} \text { of the } \\
\text { visceral cavity. }\end{array}$ \\
Ripe (Stage IV) & $\begin{array}{l}\text { Elongate and extend to occupy the entire visceral cavity } \\
\text { by attaining maximum weight and length; } \\
\text { milt extrude when pressed slightly on abdomen. }\end{array}$ & $\begin{array}{l}\text { Yellowish brown and extends throughout } \\
\text { the viscera. }\end{array}$ \\
Spent (Stage V) & $\begin{array}{l}\text { Elongated but shrunken and slightly wrinkled; colour } \\
\text { fades, occupies } 1 / 2 \text { to } 3 / 4^{\text {th }} \text { of the visceral cavity. }\end{array}$ & $\begin{array}{l}\text { Colour begins to fade, elongated but } \\
\text { shrunken and wrinkled; occupies } 1 / 2 \text { to } \\
\end{array}$ \\
\end{tabular}

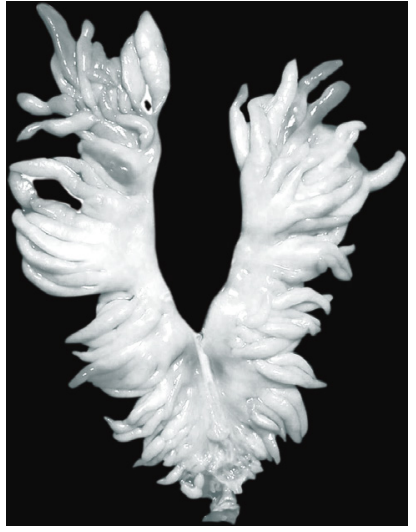

(a)

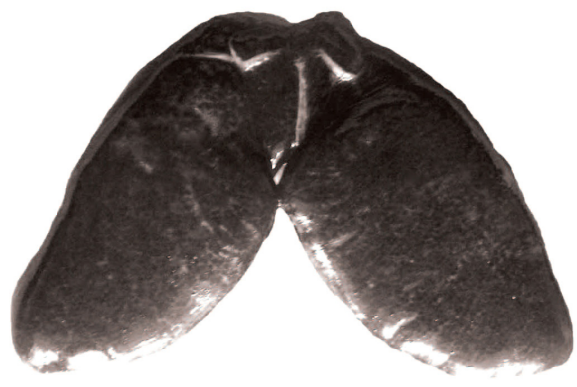

(b)

Fig. 1. Fully mature gonads of $H$. brachysoma. a) Digitiform testis; b) Ripe ovary

The size of the lobular lumen increased as testes matured i.e. at stage III (Fig. 2e, f). The walls of the lobules became thinner and most of the stages of spermatogenesis were observed. As turning silent in division, spermatogonia got restricted towards the boundary. Mature testis was characterised by many group synchronic cysts, especially with more prevalence of cysts of secondary spermatocytes and spermatids. As distended with spermatozoa in their lobular lumen, ripe or stage IV testes expanded to its maximum (Fig. 2g, h, i). Expelled out of the cysts, the resulting spermatozoa after spermiogenesis, packed the lumen of entire seminiferous lobule. They were the smallest, the most numerous and the most basophilic germ cells appearing dark blue in H\&E staining and were identified with a kidney shaped nucleus. In the spent testes (Fig. 2j), due to the elimination of spermatozoa, lobular width shortened and resembled stage III in morphological appearance with most of the central lobular walls broken, devoid of spermatozoa but containing a large number of degenerating cells, primary germ cells and a few primary spermatogonia.

\section{Morpho-histology of the ovary}

Ovaries, dual hollow sac-like organs (Fig. 1b) are positioned close together; suspended from the dorsal wall by mesovarium, the mesenteric type tissue. A thin external peritoneum and an underlying thick tunica albuginea composed of muscle fibers and connective tissue covered each ovary. The muscularis consisted of the inner circular fibers and the outer longitudinal ones; innervated and vascularised. Lining the tunica albuginea, was a single layer of germinal epithelium. It was a classic cyst type of ovary in which the tunica albuginea projected into the ovary lumen forming lobules or cysts where follicle cells and developing oocytes appeared. 


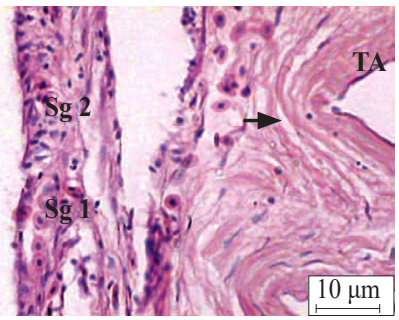

(a)

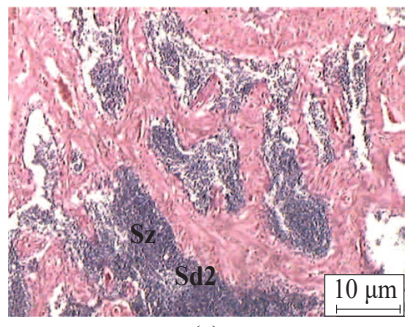

(e)

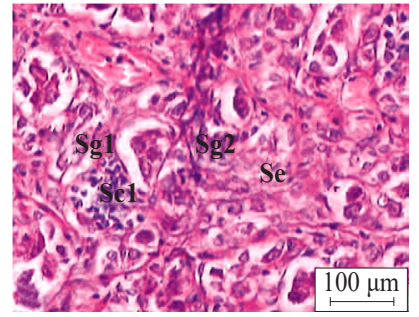

(b)

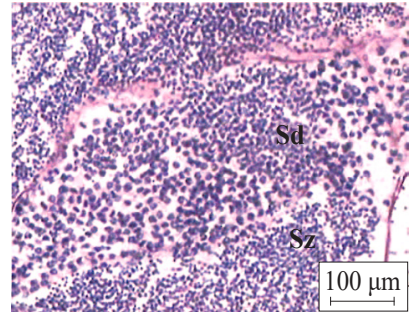

(f)

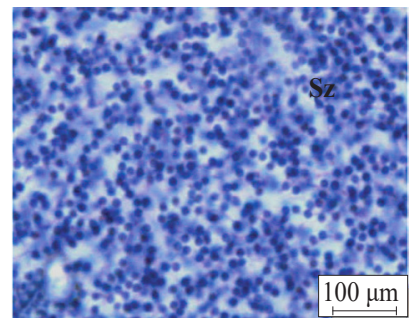

(i)

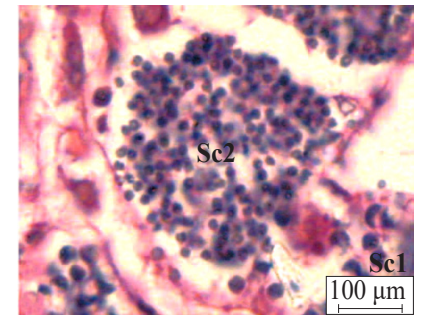

(c)

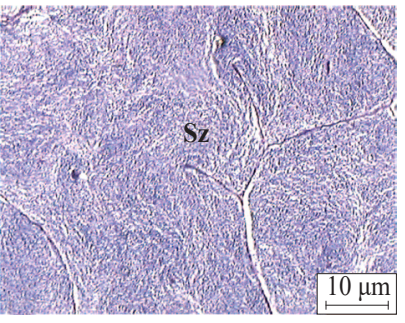

(g)

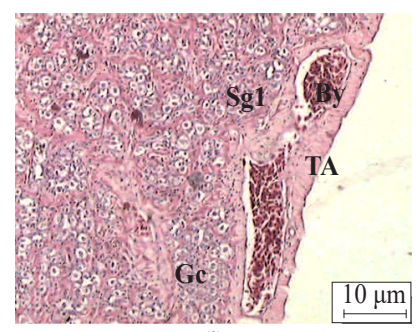

(j)

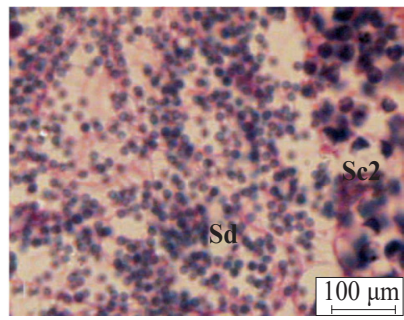

(d)

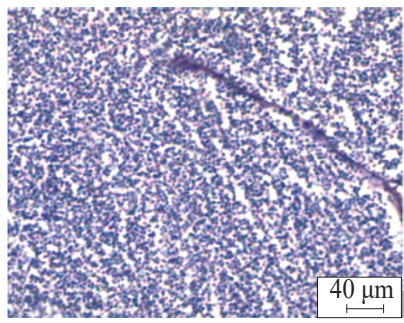

(h)

Fig. 2. (a) Immature testis with only primary and secondary spermatogonia $(\mathrm{Sg} 1 \& \mathrm{Sg} 2)$ and sertoli cells $(\mathrm{Se})$ in the diminutive, seminiferous lobules $(\rightarrow)$; Tunica albuginea (TA) covers the entire testis. (b), (c) \& (d): Maturing testis with few spermatogonia and primary spermatocytes $(\mathrm{Sc} 1)$. (e) Mature testis with spermatids $(\mathrm{Sd})$. (f) Breaking of cyst to liberate spermatids to the lumen. Spermatozoa (Sz) outside the cyst. (g), (h) \& (i) Ripe testes - seminiferous lobules are fully packed with spermatozoa. (j) Spent testis without spermatozoa but with primary germ cells $(\mathrm{Gc})$ and few spermatogonia (Sg). TA - Tunica albuginea, $\rightarrow$ Lobule, Se: Sertoli cells

\section{Oogenesis}

As the primary stage of oogenesis, pre-vitellogenic phase consisted of the first products of follicle division, the oogonia, small rounded cells with colossal sphere shaped nucleus and chromatin nucleolar oocytes having large spherical nucleus containing several small nucleoli but often with an obvious one at the fringe (Fig. $3 \mathrm{k}, 1)$.

Cytoplasmic growth phase: Cytoplasmic volume expanded, number of nucleoli increased and were seen arranged at the periphery when the oocytes passed to the early peri-nucleolar stage. Occurrence of different sized nucleoli indicated that nucleolar expurgation was still going on and only at later peri-nuclear stage, the size and number of nucleoli (20-25) got stabilised. Cytoplasmic basophilia diminished and became granular (Fig. 3m, n).

Vitellogenic stage: Peri-nuclear oocytes developed to cortical alveolar oocytes, characterised by spherical cortical granules which were optically empty initially but PAS positive ones, at the marginal cytoplasm. An acellular membrane, the zona radiata or vitelline membrane (average thickness $6.80 \mu \mathrm{m}$ ), became visible around the periphery of the oocyte. The large nucleus, with somewhat irregular margin, occupied the centre of the cell. Although maintaining their peripheral position, some of the basophilic nucleoli passed out of the nucleus into the cytoplasm. During progression, in the pronuclear and cortical zone, the cytoplasm showed a granular aspect by staining deeply. The striations of both internal and external zona radiata could be clearly distinguished. During that stage, the cortical alveoli gradually increased in size and number and filled the entire cell (Fig. 3m, n, o).

Yolky phase: The spherical yolk proteins got deposited around the oocyte nucleus and cortical alveolar layer increased and condensed. The growth of yolk granular oocytes progressed through an increase in number, size and distribution of yolk granules having an average diameter of $30.33 \mu \mathrm{m}$. Nuclear membrane surge disappeared 


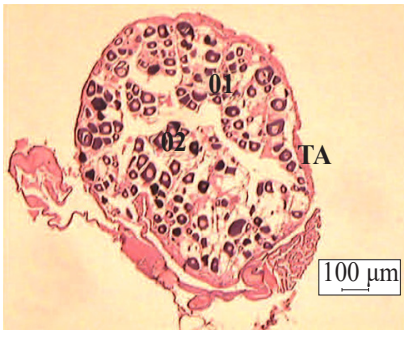

(k)

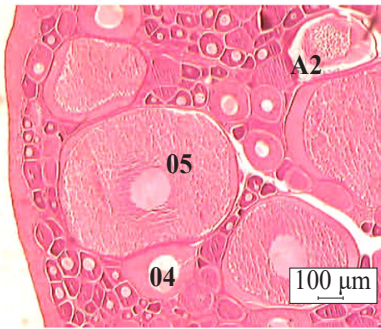

(o)

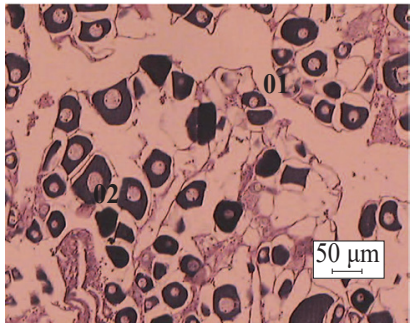

(1)

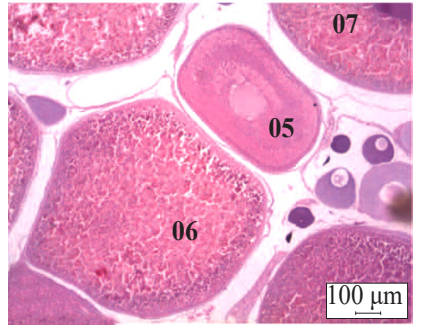

(p)

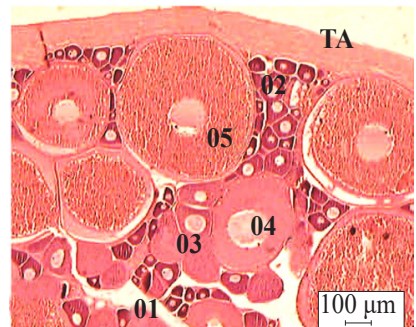

(m)

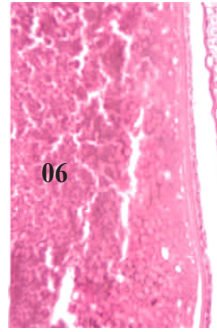

(q)

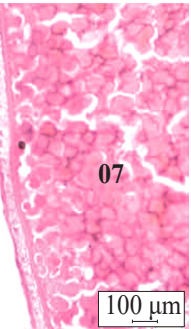

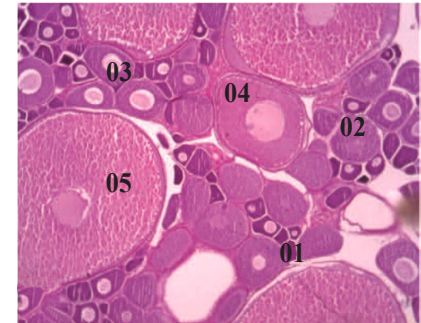

(n)

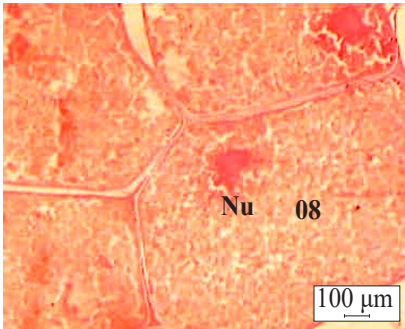

(r)

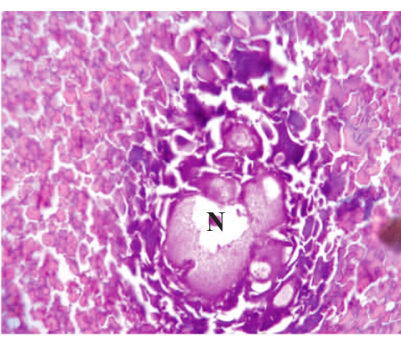

(s)

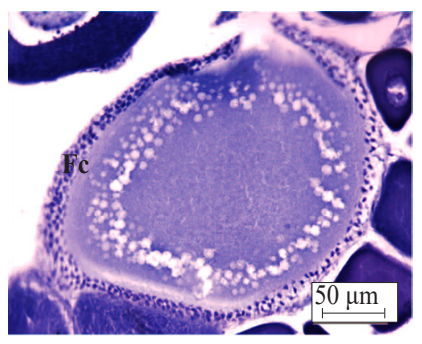

(t)

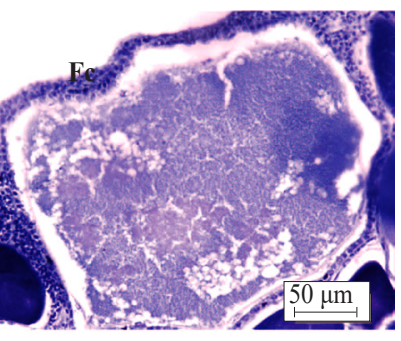

(u)

Fig. 3. (k) \& (1) C.S. of immature ovary - cyst ovarian condition with oocytes in synchronous development with follicle cells (Fc), oogonia (O1) and chromatin nucleolar oocytes (O2). (m) \& (n) Maturing ovary with peri-nuclear (O3 \&O4) and cortical alveolar oocytes (O5). (o) Vitellogenic activity in maturing ovary (PAS staining), Atretic oocyte (A2) also noticed. (p) Mature ovary with group synchronous cysts containing yolky and cortical alveolar oocytes. (q) Yolk granular (O6) and globular (O7) oocytes in mature ovary. (r) Mature oocyte $(\mathrm{O} 8)$ with nucleus $(\mathrm{Nu})$ at periphery. (s) Nuclear disintegration in mature oocyte. (t) Early atresia A1 (Alcian blue-Haematoxylin staining). (u) Late atresia A2. (v) Corpus luteum (CL). TA: Tunica albuginea, FC: Follicle cells, Nu: nucleus

indicating the onset of nuclear disintegration. At later stage, yolk granules became thicker, more globular and attained an average diameter of $36.31 \mu \mathrm{m}$. Owing to the accumulation of yolk, the oocytes enlarged. The zona radiata became very prominent and had a thickness upto $11.3 \mu \mathrm{m}$ (Fig. 3 p, q)

Mature phase: In the final phase of oogenesis, nucleus got relocated towards the animal pole of the mature oocyte. As the nuclear membrane dissolved, the contents of the germinal vesicle got intermingled with the surrounding cytoplasm (Fig. 3s). The yolk globules with a mean diameter of $41.78 \mu \mathrm{m}$ packed the entire oocyte. Ascant cortical alveolar layer was observed at the periphery. The zona radiata having an average thickness of $16.5 \mu \mathrm{m}$ showed a similar appearance as the previous stage (Fig. 3 r). The diameter of nucleus and cytoplasm, the parameters which help to identify the oocytes are given in Table 2.
Relationship between the morphological maturity stages of ovary and subsequent histological observations are summarised in Table 3.

Atretic oocytes and post-ovulatory follicles were noticed in some ovaries. Atresia observed in almost all developmental stages but predominantly in mature and vitellogenic oocytes. During the initial phase ( $\alpha$-stage), nucleus turned bumpy and granular; then disintegrated (Fig. 3t). Oocyte was discharged from the granulose; zona radiata turned irregular and dissolved. In the second phase or at $\beta$ stage (Fig. 3u), ooplasm turned vacuolated, yolk granules completely depleted and finally collapsed. The yolk granules lost their structural integrity and appeared as an eosinophilic mass. Granulose cells invaded the degenerating oocyte through the rupture of the zona radiata and phagocytosed the yolk granules. In some ovaries, layers of void and dull follicular envelops folded 
Table 2. Diameter of nucleus and oocytes at each stage of development

\begin{tabular}{lll}
\hline Stages of oocytes & Nuclear dia $(\mu \mathrm{m})$ & Oocyte dia $(\mu \mathrm{m})$ \\
\hline Oogonia & 16.2 & 34.5 \\
Chromatin nucleolar & 36.99 & 89.80 \\
Early peri nuclear & 59.54 & 156.84 \\
Late peri nuclear & 110.73 & 246.56 \\
Cortical alveolar & 208.75 & 517 \\
Yolk granular & 215.5 & 740 \\
Yolk globular & $*$ & 990 \\
Mature & $*$ & 1200 \\
\hline
\end{tabular}

*Nucleus disintegrated spermatogenic activity restricted to cranial and middle fringes while the caudal fringes were exclusively secretory (Guimaraes -Cruz et al., 2005). But in H. brachysoma, spermatogenic activity was observed along the entire length. It is well accepted that in many teleosts, the germ cells develop synchronously in cysts throughout the whole seminiferous lobules. The seminiferous tubules of the marine catfish family, Ariidae also possessed synchronic cysts of spermatogenic cells at various developmental stages (Gomes and Araujo, 2004).

In many teleosts, the cysts were retained until the entire process of spermatogenesis was completed and

Table 3. Relationship between the morphological stages of ovary and histological stages of oocytes

\begin{tabular}{ll}
\hline Ovarian stages & Histological stages of oocytes \\
\hline Immature (Stage1) & Follicle cells, oogonia, chromatin nucleolar \\
Maturing (Stage II) & Chromatin nucleolar, early and late peri-nucleolar, cortical granular \\
Mature (Stage III) & $\begin{array}{l}\text { Few late peri- and chromatin nucleolar, cortical granular with the predominance of yolk granular and yolk } \\
\text { globular oocytes and some mature oocytes }\end{array}$ \\
$\begin{array}{l}\text { Ripe (Stage IV) } \\
\text { Yolk globular and mature oocytes }\end{array}$ \\
\hline
\end{tabular}

to form compact complex structures called corpus luteum (Fig. 3v). Tapered granulose cells with a conspicuous nucleus, convoluted post-ovulatory follicles with a reduced lumen, eosinophilic granules and oocytes in different stages of reabsorption were embedded in the corpus luteum

Digitiform testes had been observed in several siluriform families such as Nearctic, Ictaluridae (Sneed and Clemens, 1963), Afro-Asian, Clariidae (Sircar, 1970) and both the Neotropical Pimelodidae (Loir et al., 1989) and Auchenipteridae (Meisner et al., 2000). The caudally joined and fringed testicular morphology without seminal vesicles and accessory glandular structures in H. brachysoma (Fig. 1a) was analogous to those observed in the Pimelodid catfishes (Guimaraes-Cruz and Santos, 2004; Barros et al., 2007) and South American Conorhynchus conirostris (Lopes et al., 2004). On the other hand, Afro-Asian clades like Heteropnesutes fossilis (Nayyar and Sunderraj, 1970), Clarias batrachus (Mansour et al., 2003) and Heterobranchus longifilis (Oteme et al., 1996) possessed testes having fringed morphology with seminal vesicles.

Testes of $H$. brachysoma could be categorised as 'unrestricted lobular type' according to 'testes types' defined by Grier and Parenti (2004). Some neotropical catfishes from the family Pimelodidae like Iheringichthys laborious (Santos et al., 2001), Pimelodus maculates (Guimaraes-Cruz and Santos, 2004) and Loricaria lentiginosa (Guimaraes-Cruz et al., 2005) had such condition was called cystic as observed in Labeo victorianus (Rutaisire et al., 2003). But in some fishes approaching the final stage of spermatogenesis, the cysts collapsed previous to the spermatozoa stage and spermiogenesis was completed outside the cysts i.e. in the lumen of the seminiferous lobules. The condition was referred semicystic (Mattei et al., 1993) as in Nile electric catfish, Malapterurus electricus (Shahin, 2006) and in certain catfishes of Neotropical families Aspredinidae and Cetopsidae (Grassiotto et al., 2005). This type of spermatogenesis had also been reported by Davis (1977) in an Australian plotosid catfish, Tandanus tandanus in which spermatids detached from the lobule wall and metamorphosed to spermatozoa within the seminiferous lobular lumen itself. The breaking of cysts to liberate spermatids (Fig. 2f) into the lumen of lobules could be observed in the spermiogenesis giving a semi-cystic spermatogenic appearance.

This study is the first attempt of histological identification of oocyte developmental stages and characterisation of ovarian cycle in a horabagrid catfish. Generally following a typical teleostean pattern of development, the sequence of oocyte maturation in $H$. brachysoma resembled that in Clarias macrocephalus (Mollah, 1986) and Asian bagrid Mystus montanus (Arockiaraj et al., 2004). Generally, two or three stages of oocyte development were observed in the ovary of samples at any stage. The mature ovary at the same time contained oocytes in two or three different synchronic groups of development (Table 3). According to West (1990), group- 
synchronous ovaries were characterised by the presence of at least two size groups of oocytes at the same time. As per our observation, $H$. brachysoma belonged to the group synchronous class (Fig. $3 p$ ) in which spawning took place in a single breeding season as in Clarias gariepinus (Cek and Yilmaz, 2007). Spawning in some catfishes as Afro-tropical Amphilius natalensis (Marriott et al., 1997), Neotropical Iheringichthys labrosus (Santos et al., 2004) and Trichomycterus corduvense (Marraro and Bistoni, 2005) were asynchronous where there is simultaneous development of a number of clusters of oocytes in the ovarian parenchyma and continuous spawning occurred throughout the year. According to Connaughton and Aida (1998) species with group-synchronic oocyte development, exhibited multiple spawning acts, even if for a shorter period of time than those that have asynchronous development. In some group-synchronous fishes like Gerlachea australis (Molen and Matallanas, 2003), two distinct clutches of oocytes were distinguished in the ripe ovary with a hiatus separating them: a large clutch of vitellogenic and maturing oocytes with homogeneous development and a second clutch comprising diverse stages of pre-vitellogenic and cortical alveolar oocytes. The most advanced clutch was the one to be spawned in the current season while the other would form the reserve stock for the next spawning season. There was no such reserve stock of primary developmental stages in the fully mature ovary of $H$. brachysoma that contained only synchronic batch of most advanced stages i.e., eggs only at yolky and mature stages confirming a single breeding season.

Vitellogenesis or accumulation of yolk, which is destined for embryo and larval nutrition, is an important feature of developing oocytes in teleosts (Jalabert, 2005). In the present study, the yolk deposition started in the oocytes of maturing ovary (stage II) which is clearly justified by the positive reactions to PAS (Fig. 3o). The yolk vesicle followed the same centripetal sequence of development as in T. tandanus (Davis, 1977). Similar to I. labrosus, yolk was stored as granules or globules until the end of oocyte maturation, exhibiting no fusion or liqueification of the contents (Santos et al., 2006). But as a characteristic of vitellogenesis in marine teleosts (Wallace and Selman, 1981), the sea catfishes, Sciadeichthys luniscutis and Genidens genidens showed fusion of oocyte yolk granules into a homogeneous mass, creating "hyaline oocyte" or hydrated oocytes (Gomes and Araujo, 2004). The structure, thickness and macromolecular composition of the zona radiata shows adaptations to differing ecological conditions (Stehr and Hawkes, 1979). But in loricariid catfishes, it was thick due to great physical exposure when eggs were carried by males on dorsal surface (Suzuki et al., 2000). The zona radiata of $H$. brachysoma was very prominent and had a thickness upto $16.5 \mu \mathrm{m}$ and comprised only neutral glycopolysaccharides justified by the positivity to PAS but negativity to alcian blue. Further, electron microscopic investigations are needed to elucidate the structural details of the vitelline membrane.

Digitiform testes lacking seminal vesicles, with unrestricted semi-cystic spermatogenic activity was found to be the peculiarity of the male genital system. Group synchronic developments of oocytes with seven histological stages in the cystovarian ovary which passed through five morphological maturity stages and fairly prolonged single spawning period were the noted characteristics of ovarian development in H. brachysoma.

\section{Acknowledgements}

Authors sincerely acknowledge Kerala State Council for Science Technology and Environment (KSCSTE), Government of Kerala for the financial assistance rendered for the study.

\section{References}

Ali, A. P. H., Raghavan, R. and Prasad, G. 2007. Threatened fishes of the world: Horabagrus brachysoma (Gunther, 1864) (Bagridae). Environ. Biol. Fishes, 7: 221-221.

Arockiaraj, J. A., Haniffa, M. S., Seetharaman, S. and Singh, S. 2004. Cyclic changes in gonadal maturation and histological observations of threatened freshwater catfish, Mystus montanus. Acta Ichthyol. Piscatoria, 34: 253-266.

Barros, M. D. M., Guimaraes-Cruz, J. R., Vanderlei, C., Veloso Junior and Santos, J. E. 2007. Reproductive apparatus and gametogenesis of Lophiosilurus alexandri, Steindachner (Pisces, Teleostei, Siluriformes). Rev. Brasil Zool., 24: 213-221. doi.org/10.1590/S0101-81752007000100028.

Cek, S. and Yilmaz, E. 2007. Gonad development and sex ratio of sharp tooth atfish Clarias gariepinus (Burchell, 1822) cultured under laboratory onditions. Turkish J. Zool., 1: 35-46.

Chowdhury, I. and Joy, K. P. 2007. Seminal vesicle and its role in the reproduction of teleosts. Fish Physiol. Biochem., 33 383-398. DOI: 10.1007/s10695-007-9162-5.

Connaughton, M. A. and Aida, K. 1998. Female reproductive system in fish. In: Knohil and Neill, J. D (Eds.), Encyclopedia of reproduction. Academic Press, London, p. 193-204.

Davis, T. L. O. 1977. Reproductive biology of freshwater catfish, Tandanus tandanus Mitchell, in the Gwydir River, Australia I. Structure of the gonads. Aust. J. Mar. Freshw. Res., 28: 139-158.

Gomes. I. D. and Araujo, F. G. 2004. Reproductive biology of two marine catfishes (Siluriformes, Ariidae) in the Sepetiba Bay. Rev. Biología Trop., 52: 143-156. 
Grier, H. J. and Parenti, L. R. 2004. Evolution and phylogeny of gonad morphology in bony fishes. Integr. Comp. Biol., 44: 333-348. doi: 10.1093/icb/44.5.333.

Grassiotto, I. Q., Spadella, M. A., Carvalho, M. and Oliveira, C. 2005. Comparative description and discussion of spermiogenesis and spermatozoal ultrastructure in some species of Heptapteridae and Pseudopimelodidae (Teleostei: Siluriformes). Neotro. Ichthyol., 3: 401-410. doi.org/10.1590/S1679-62252007000300014.

Guimaraes-Cruz and Santos J. E. 2004. Testicular structure of three species of Neotropical freshwater Pimelodids (Pisces, Pimelodidae). Rev. Brasil. Zool., 21: 267-271. doi. org/10.1590/S0101-81752004000200016.

Guimaraes-Cruz, R. J., Santos, J. E. and Santos, G. B. 2005. Gonadal structure and gametogenesis of Loricaria lentiginosa Isbrucker (Pisces, Teleostei, Siluriformes). Rev. Brasil. Zool., 22: 556-564. doi.org/10.1590/S010181752005000300005 .

Hoar, W. S. 1969. Reproduction. In: Hoar, W. S. and Randall, D. J. (Eds.), Fish physiology. Academic Press, New York, p. 1-72. doi.org/10.1002/iroh.19710560141.

Jalabert, B. 2005. Particularities of reproduction and oogenesis in teleost fish compared to mammals. Reprod. Nutr. Develop., 45: 261-279. DOI:10.1051/rnd:2005019.

Legendre, M., Linhart. O. and Billard, R. 1996. Spawning and management of gametes, fertilised eggs and embryos in Siluroidei. Aquat. Liv. Resour., 9: 59-80.

Loir, M., Cauty, C., Planquette, P. and Bail, P. Y. 1989. Comparative study of the male reproductive tract in seven families of South-American catfishes. Aquat. Liv. Resour., 2: $45-56$.

Lopes, D. C., Bazzoli, N. J. R., Brito, M. F. G. and Maria, T. A. 2004. Male reproductive system in the South American catfish Conorhynchus conirostris. J. Fish Biol., 64: 1419-1424. DOI: 10.1111/j.0022-1112.2004.00377.x.

Mansour, N. and Lahnsteiner, F. 2003. Morphology of male genitalia and sperm fine structure in siluroid fish. J. Submicrosco. Cytol. Pathol., 35: 277-285. DOI: 10.1016/ S1096-4959(03)00083-6.

Mansour, N., Lahnsteiner, F. and Berger, B. 2003. Metabolism of intra-testicular spermatozoa of a tropical teleost fish (Clarias gariepinus). Comp. Biochem. Physiol., 135: 285-296.

Mansour, N., Lahnsteiner, F. and Patzner, R. 2002. The spermatozoa of the African catfish: fine structure, motility, viability and its behavior in seminal vesicle secretion. J. Fish Biol., 60: 545-560. doi.org/10.1111/j.1095-8649. 2002.tb01683.x.

Marraro, F. M. and Bistoni, M. A. 2005. Spawning season, ovarian development and fecundity of female Trichomycterus corduvense (Osteichthyes, Siluriformes). Hydrobiologia, 534: 223-230. DOI: 10.1007/s10750-004-1635-2.
Marriott, M. S., Booth, A. J. and Skelton, P. H. 1997. Reproductive and feeding biology of the Natal mountain catfish, Amphilius natalensis (Siluriformes: Amphiliidae). Environ. Biol. Fish., 49: 461-470.

Mattei, X., Siau, Y., Thiaw, O. T. and Thiam, D. 1993. Peculiarities in the organisation of testis of Ophidion sp. (Pisces: Teleostei), evidence for two types of spermatogenesis in teleost fish. J. Fish Biol., 43: 931-937. DOI: 10.1111/ j.1095-8649.1993.tb01167.x.

Meisner, A. D., Burns, J. R., Weitzman, S. H. and Malabarba, L. R. 2000. Morphology and histology of the male reproductive system in two species of internally inseminating South American catfishes, Trachelyopterus lucenai and T. galeatus (Teleostei: Auchenipteridae). J. Morphol., 246: 131-142. doi.org/10.1002/1097-4687(200011)246:2<131: AID-JMOR7>3.0.CO;2-K.

Molen, M. S. V. and Matallanas, E. J. 2003. Oocyte development and maturity classification of Gerlachea australis from the Weddell Sea, Antarctica. Polar Biol., 26: 653-658. DOI: $10.1007 / \mathrm{s} 00300-003-0542-8$.

Mollah, M. F. A. 1986. Cyclic changes in the ovary of a freshwater catfish, Clarias macrocephalus (Gunther). Indian J. Fish., 33: 54-65.

Nayyar, S. K. and Sunderraj, B. I. 1970. Seasonal reproductive activity in the testes and seminal vesicles of the catfish, Heteropneustes fossilis (Bloch). J. Morphol., 130: 207-225. doi.org/10.1002/jmor.1051300207.

Oteme, Z. J., Rodriguez, J. N., Kouassi, C. K., Hem, S. and Agnes J. F. 1996. Testicular structure, spermatogenesis and sperm cryopreservation in the African clariid catfish Heterobranchus longifilis (Valenciennes, 1840). Aquac. Res., 27: 805-813.

Padmakumar,K.G., Bindu,L.,Sreerekha,P.S., Gopalakrishnan,A., Basheer, V. S., Joseph, N., Manu, P. S. and Krishnan, A. 2011. Breeding of endemic catfish, Horabagrus brachysomain captive conditions. Curr. Sci., 100(8): 1232-1236.

Pearse, A. G. E. 1968. Histochemistry: Theoretical and applied. J. \& A. Churchill Ltd., London.

Prasad, G., Ali, A. P. H. and Raghavan, R. 2008. Threatened fishes of the world: Horabagrus nigricollaris (Pethiyagoda and Kottelat, 1994) (Bagridae). Environ. Biol. Fish., 82: 109-110. DOI: 10.1007/s10641-007-9259-9.

Prasad, G. 2014. Protein requirement of Horabagrus brachysoma (Gunther 1864) an endemic and threatened catfish from Western Ghats region. J. Aquat. Biol. Fish., 1-2(1): 194-200.

Rastogi, R. K. 1969. Seminal vesicles and sperm duct of an Indian catfish, Mystus tengara (Ham), with particular reference to their seasonal cycle. Acta Anat., 72: 624-639. DOI:10.1159/000143272. 
Rutaisire, J., Muwazi, R. T. and Booth, A. J. 2003. Structure and cytology of the testes of Labeo victorianus (Pisces: Cyprinidae). African J. Zool., 38: 119-126. DOI: $10.1080 / 15627020.2003 .11657199$.

Sahoo, S. K., Ferosekhan, S., Saha, A., Giri, S. S. and Paramanik, M. 2017. Embryonic and larval development of an endangered catfish, Horabagrus brachysoma. Indian J. Anim. Res., 51(1): 15-20.

Sahoo, S. K., Ferosekhan, S., Saha, A., Giri, S. S. and Paramanik, M. and Radhakrishnan, K. 2018. Reports on common deformities in induced bred Horabagrus brachysoma larvae. J. Entomol. Zool. Studies, 6(3): 462-465.

Santos, J. E., Bazzoli, N., Rizzo, E. and Santos, G. B. 2001. Morpho-functional organisation of the male reproductive system of the catfish Iheringichthys labrosus (Lutken, 1874) (Siluriformes: Pimelodidae). Tissue Cell., 33: 533-540. DOI:10.1054/tice.2001.0207.

Santos, J. E., Bazzoli, N., Rizzo, E. and Santos, G. B. 2004. Reproduction of the catfish Iheringichthys labrosus (Lutken) (Pisces, Siluriformes) in Furnas Reservoir, Minas Gerais, Brazil. Rev. Brasil. Zool., 21: 193-200. doi. org/10.1590/S0101-81752004000200006.

Santos, J. E., Padilha, G. E. V., Junior, B., Bazzoli, N., Rizzo, E. and Santos, G. B. 2006. Ovarian follicle growth in the catfish Iheringichthys labrosus (Siluriformes: Pimelodidae). Tissue Cell., 38: 303-310. DOI:10.1016/j. tice.2006.07.002.

Shahin, A. A. B. 2006. Semi-cystic spermatogenesis and biflagellate spermatozoon ultrastructure in the Nile electric catfish Malapterurus electricus (Teleostei: Siluriformes: Malapteruridae). Acta Zool., 87: 215-227.

Sircar, A. K. 1970. Morphology of urinogenital system of some siluroid fishes. Proc. Zool. Soc. Calcutta, 23: 93-117.

Sneed, K. E. and Clemens, H. P. 1963. The morphology of the testes and accessory reproductive glands of the catfishes (Ictaluridae). Copeia, 4: 606-611.

Stehr, C. M. and Hawkes, J. W. 1979. The comparative ultra structure of the egg membrane and associated pore structures in the starry flounder Platichthys stellatus (Pallas) and pink salmon, Oncorhynchus gorbuscha (Walbaum). Cell. Tissue Res., 202: 347-356. DOI:10.1007/BF00220430.

Sullivan, J. P., Lundberg, J. G. and Hardman, M. 2006 A phylogenetic analysis of the major groups of catfishes (Teleostei: Siluriformes) using rag1 and rag2 nuclear gene sequences. Mol. Phylo. Evol., 41: 636-66. DOI:10.1016/j. ympev.2006.05.044

Suzuki, H. J., Agostinho, A. A. and Winemiller, K. A. 2000. Relationship between oocyte morphology and reproductive strategy in loricariid catfishes of the Parana River, Brazil. J. Fish Biol., 57: 791-807.

Unver, B. and Saraydin, S. U. 2004. Histological examination of ovarium development of shemaya, Chalcalburnus chalcoides living in Lake Todurge (Sivas /Turkey). Folia Zool., 53: 99-106.

Wallace, R. A. and Selman, K. 1981. Oocyte Growth and Recruitment in Teleosts. Bio Sci., 31: 323-324.

West, G. 1990. Methods of assessing ovarian development in fishes: a Review. Aust. J. Mar. Freshw. Res., 41: 199-22. DOI: $10.1071 / \mathrm{mf} 9900199$. 